\title{
Business relations between Ukraine and China: development options
}

\author{
Andrew Pochtovyuk ${ }^{1, *}$, Victoria Semenikhina ${ }^{2}$ \\ ${ }^{1}$ D.of Economics, Professor, Management Department, 39600 Kremenchuk Mykhailo Ostrogradsky \\ national University, Kremenchuk, Pershotravneva str. 20, Ukraine \\ ${ }^{2}$ Senior lecturer, Management Department, 39600 Kremenchuk Mykhailo Ostrogradsky national \\ University, Kremenchuk, Pershotravneva str. 20, Ukraine
}

\begin{abstract}
In the article were analyzed the present state of business relations of Ukraine and People's Republic of China (PRC). Investigations of state threats to economic security were made; options of changes in the commodity flows structure were suggested, as well as the prospects of cooperation between the two countries on the basis of maximizing the volume of domestic high technology products exports and minimizing Ukraine's dependence on the ever-increasing role of China in the global economic space were considered.
\end{abstract}

Key words: business relations, commodities, export, economic security

\section{Introduction}

The Chinese role in the world economy, with its stable growth trend, the prospects of the international Ukrainian-Chinese relations in general and trade in particular, have today both favorable and negative impact on the Ukrainian economic development .

In this regard, the external economic relations between Ukraine and the People's Republic of China (the PRC) are subject to a thorough studying of both Ukrainian and Chinese economists. Thus, Ukrainian scientists, Vlasenko [1], Vysotskaya [2], Levkivsky [3] in their researches noted that the current problem: substantiation of the basic directions of interaction, the impact on the State economic security, the problems of relationships strengthening and broadening require thorough analysis and studying with the subsequent development of recommendations on optimization of the Ukrainian-Chinese relations structure.

\section{Data and Methods}

Methodological study basis accommodates the general and special scientific conceptions, theories and methods. The methods of obtaining knowledge, such as dialectical, historical, and systematic and others are used as methodological basis of the study. Thus, the dialectical method is used for investigation of the phenomena "the technological and innovative component of the Ukrainian-Chinese trade" that gives the ability to review them

${ }^{*}$ Corresponding author: andrey.pochtovyuk@gmail.com 
as a dynamic category. Historical method was used first of all in the analysis of business relations of Ukraine and People's Republic of China. Systematic method was used in evaluation of the creation business relations between Ukraine and China at this stage and selecting the options for their development.

\section{Results and Discussion}

The role of China in world markets is constantly growing, and the share of world trade has increased from $0.75 \%$ in 1948 to $12 \%$ in 2015, and now it's about 4 trillion US dollars [4]. According to the Ukrainian State statistics service in the structure of external trade turnover for 2001-2015 China's share amounted on an average of $4.69 \%$ (from $3.08 \%$ of total export, and $6.04 \%$ of total import) [5] (Table 1).

For China, as a state with more than a billion people (1.379 billion people - 2016), the most pressing is food problem. In the ranking of World health organization, China ranks second place in the world after India in the number of people suffering from malnutrition (about 130 million people). The increase food and agricultural products trade is the real breakthrough for Ukraine in realization of domestic natural resource potential, providing the sustainable development of agricultural sector.

However, the increase in agricultural products exports can cause fallout. Thus, in 2015, the main exports of agricultural products to China were maize (542,596 million US dollars or of $22.61 \%$ of exports to China) and sunflower oil (438 million US dollars or $18.27 \%$ of export volumes) [6]. The keen interest of China to Ukrainian sunflower oil import creates threats related to excessive expansion of sunflower cultivation that will ultimately lead to the soils depletion, and will cause irreparable harm to Ukrainian agriculture for a long period.

It is should be noted that China remains one of the main business partners of Ukraine in the military-industrial products market. In 1992 Ukraine and China signed about 200 contracts in the military sector. During 1992-2008 the volume of arms imports to China amounted about 624 million US dollars [7].

First of all it's aircraft and air defense systems. The main group of domestic goods exported to China, was weapons which other exporters ignored mostly for political reasons. Ukrainian military-technical production is very attractive for China because of its high adaptability and low price in comparison with competitors. However, the Chinese government pursues active policy of all around support of domestic military industry development. Thus, the competitive advantages of the Ukrainian military-technical production become unstable and gradually are leveled off. In view of this there is only one solution - collaboration in the projects and technologies development which are inaccessible for the military-industrial complex enterprises of the PRC.

The structure of import from China to Ukraine in 2015 is more balanced, the production means amounted to $26,14 \%$ (982,22 million US dollars) total imports; intermediate goods - 48.13\% (1808,28 million US dollars, consumer goods - of $25.73 \%$ - 966,75 million US dollars).

The increase in the share of mineral raw materials is characterized by the simultaneous decrease of partners' interest from China in finished and intermediate industrial products of domestic producers, especially concerning the trade in iron and steel. In 2001, this product group was dominated in the nomenclature of the Ukrainian-Chinese export trade $(378.26$ million US dollars or $78 \%$ of total domestic imports). In 2015, this figure decreased to 20.1 thousand US dollars, which accounted less than $1 \%$ of total exports to China [8]. 
Table 1. Dynamics of business relations indicators between Ukraine and China, billion US dollars*

\begin{tabular}{|c|c|c|c|c|c|c|c|c|c|c|c|c|c|c|c|}
\hline & ঠ্ণ & 용 & 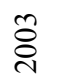 & ঠ্ণ & ஜ̊ & ๖̊ & 홍 & $\stackrel{\infty}{\stackrel{ᄋ}{ᄋ}}$ & ஓి & $\stackrel{\circ}{\stackrel{0}{0}}$ & $\overline{\overline{0}}$ & 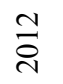 & $\stackrel{m}{\stackrel{2}{2}}$ & 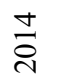 & 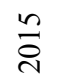 \\
\hline Exports & 0,48 & 0,67 & 1,00 & 0,82 & 0,71 & 0,54 & 0,43 & 0,55 & 1,43 & 1,32 & 2,18 & 1,78 & 2,73 & 2,67 & 2,40 \\
\hline Imports & 0,20 & 0,26 & 0,52 & 0,74 & 1,81 & 2,31 & 3,31 & 5,60 & 2,73 & 4,7 & 6,27 & 7,9 & 7,90 & 5,41 & 3,77 \\
\hline ET & 0,68 & 0,93 & 1,52 & 1,56 & 2,52 & 2,85 & 3,74 & 6,15 & 4,17 & 6,02 & 8,45 & 9,68 & 10,63 & 8,08 & 6,17 \\
\hline Balance & 0,29 & 0,41 & 0,48 & 0,08 & $-1,1$ & $-1,8$ & $-2,9$ & $-5,1$ & $-1,3$ & $-3,4$ & $-4,1$ & $-6,1$ & $-5,2$ & $-2,7$ & $-1,4$ \\
\hline REI & 2,48 & 2,58 & 1,93 & 1,11 & 0,39 & 0,24 & 0,13 & 0,10 & 0,52 & 0,28 & 0,35 & 0,22 & 0,35 & 0,49 & 0,64 \\
\hline
\end{tabular}

ET - external turnover, REI - the ratio of export to import

*According to the data [4].

In accordance with the available data the share of production in total exports is now $1.58 \%$ (37.77 million US dollars); intermediate goods - $97.76 \%$ (2338,23 million US dollars), consumer goods $-0.66 \%$ (15.79\% million US dollars) [9].

The technological and innovative component of the Ukrainian-Chinese trade remains at a very low level. This means that Ukraine is China's mainly raw materials exporter with low added value and the importer of finished products with relatively high added value, mainly commodities (Fig. 1).

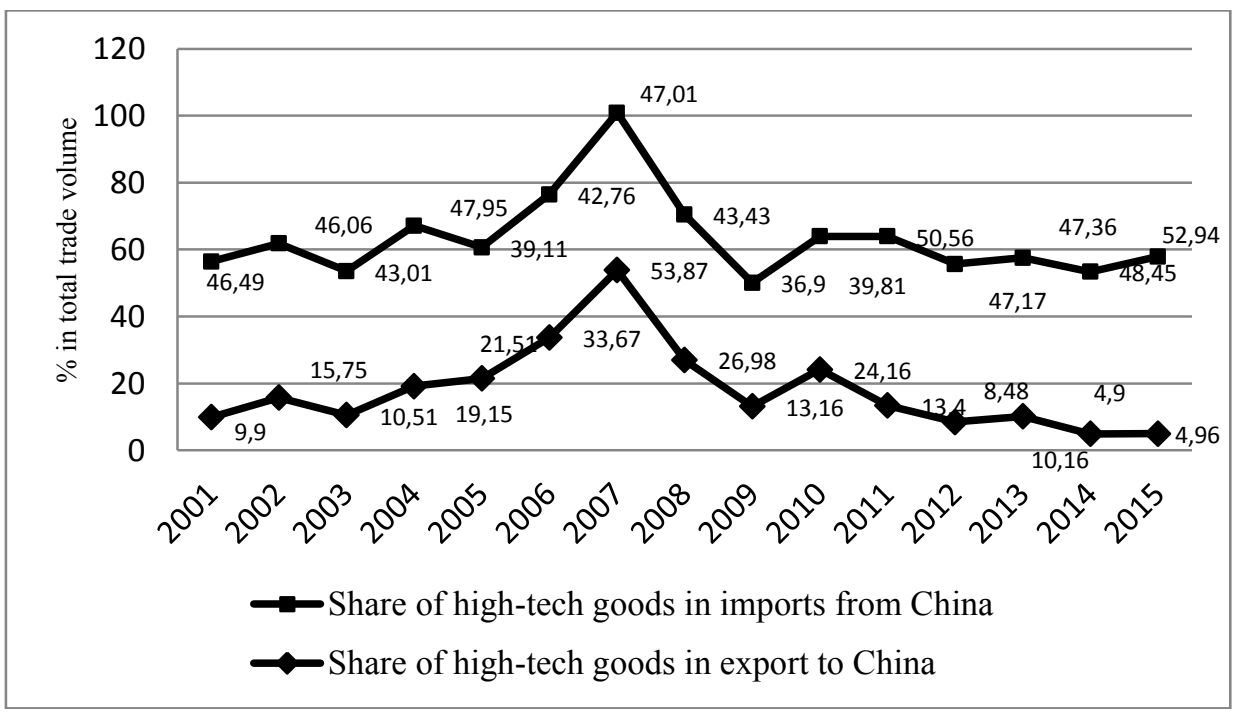

Fig. 1. Dynamics of high-tech products in business relations between Ukraine and China, 2001-2015.

It should be noted the existing trend of trade turnover growth between our countries, that is a confirmation of the thesis that China is the leading trade partner of Ukraine among 
the Asian countries. In 2015, the volume of Ukrainian-Chinese trade turnover made up 8.08 billion US dollars or $28.5 \%$ of Ukrainian volumes of foreign trade relations with the Asian region countries $(17.26 \%$ of Ukraine's exports to Asia; $48.84 \%$ of imports from Asia to Ukraine) it's $21.24 \%$ higher than total trade turnover with the Republic of Turkey (4.86 billion US dollars), which ranks the second place among Asian countries-partners of Ukraine in 2015 [6].

However, the dynamics of trade relations development of Ukraine and China is not the only positive aspect in bilateral relations totally and in economic security in particular. This is confirmed by the figures of goods exports and imports and trade balance, the coverage of goods imports by exports, that is indicating the instability situation on the basis of imports over exports prevalence. In fact, the coverage ratio of imports by exports is less than one since 2005 (in 2015: 0.64) and balance of external trade turnover is negative (in 2015: -1, 37 billion US dollars) that does not correspond to the boundary values of the state external economic safety [6].

To search and identify the main vectors of Ukrainian-Chinese trade the predominant groups of goods, the ratio of raw materials and finished products in the exports and imports structure, the technological level of the goods turnover, the general trends of trade development should be established.

The existing Program of strategic partnership relations development between Ukraine and China for 2014-2018 should become the basis for the taking new level of interstate relations and cooperation in specific directions and branches. There is a mutual desire of the parties to increase the volume of bilateral trade, diversification of its structure, the development of long-term forms of economic cooperation, deepening of investment cooperation between Ukraine and China.

Relations between the two countries are still developing: for the 6 months of 2016 the total trade turnover has increased by $0.8 \%$ compared to 2015 and has reached 4.3 billion US dollars. However, the amount of Chinese direct investment in the Ukrainian economy is far from desirable and there are objective reasons for it. The business pools of our countries can gain plenty by collaborating and working together. Progressive advance of developing contacts between economic entities and the continued deployment of joint production bases is important for both sides.

Such branches as transportation, agriculture, infrastructure creation, aviation, space, innovation, scientific-technical and other fields are strategic for mutually beneficial cooperation development. Future-oriented strategic direction of economic cooperation with China is the direct involvement of Ukraine in the implementation of the development the Silk Road economic belt initiated by the President of China. Ukraine intends to participate actively in the concept implementation "One zone, one way", and to become a part of New "Silk Road".

Ukraine intends to use the Chinese initiative "One zone, one way" to strengthen the cooperation with China in transportation and communication so as in infrastructure branches. The advantageous geographical location of Ukraine, the country is at the crossroads of major transit routes between Europe and Asia, it has 18 ice-free ports on the Black sea (five of which are in the temporarily occupied territory), an extensive network of railways and automobile roads facilitate to this. This point is particularly relevant in connection with the EU Association Agreement and the further Ukraine integration into the transport system of corridor "Europe-Asia-Europe". Odessa sea port is the largest port in Ukraine which is simultaneously the main point of the IX Trans-European corridor.

It also should be mentioned about the Beskids tunnel reconstruction completion that is the strategic in relation of transit goods delivery towards the European countries and is the part of V pan-European transport corridor (Italy - Slovenia-Hungary-Slovakia-Ukraine). 
Having all the above mentioned features and the potential Ukraine strives to become a bridge between Asia and Europe turning the existing potential into the business opportunities. Ukraine may be an important hub in logistical operations of Chinese goods to EU markets and goods of domestic and European manufacturers back to China. Ukraine together with its partners trashes out the best possible conditions for container traffic through the country ports. In the estimation of Ukrainian railway department containers transportation can take up to 15 days within the new corridor in the case of synchronization of the maritime (railway ferry) and railway sections work. Ukraine together with its partners are focused on formation new logistic chains and the integration of national transport networks into a global network of international transport.

The National Development and Reform Commission of China expect that there will be about 5,000 freight trains plying between China and Europe every year till 2020. 43 transportation hubs and 43 railway lines will be constructed. Ukraine with its seaports and well-developed railway infrastructure is a transportation gateway between East and West, North and South building its transit and transportation strategy to meet the initiatives of China on cooperation in the regions of the Adriatic, Baltic and Black seas. In this regard the work with Chinese partners first of all in creating the effective model of Ukrainian ports using is of great importance.

Now the Chinese economy faced the necessity of development model change. The current model has demonstrated (and continues to demonstrate) unprecedented pace mainly due to foreign investment and rapidly growing exports. Although this model with its role and scope (the second largest economy in the world after the United States and first by volumes of world exports), can not be quickly upgraded the Chinese government wants to minimize the risks of external shocks, the threat of which increases in the growing problems of China economic development.

Among the key challenges that will influence the content and dynamics of UkrainianChinese relations, we can emphasize the following: the restructuring of China's economy; a change in the quality of economic growth, transition from extensive development to improvement the production manufacturability. At the moment a lot of Chinese enterprises, especially in the public sector, will remain uncompetitive as before and will be forced to face serious financial difficulties if the government cancels the subsidies, which include land and energy assistance now. For bilateral cooperation, the emphasis alteration in the national development of China will affect the competition growth between companies that have similar competitive advantages and are equally interested in building up the technological capabilities and to the new markets access. Keeping in mind that China has set a goal to become a leader in the production of not only goods but also services and technologies Ukraine can benefit from participation in the new products creation as a partner (or orders executive) [6].

We can predict that promotion in the Chinese market the Ukrainian engineering products and other technological multi-purpose products (and/or finished products) will occur hard. Therefore, the optimal form of consolidation of the Ukrainian manufacturers on the Chinese market may be the implementation of joint sectorial and/or regional projects to solve specific problems such as energy, environmental, scientific and technological and etc. A gradual increase in domestic demand that will make compensation for the decline in external demand increases the possibility for the Ukraine to bring the products to the Chinese market which it lacks. At a time of high savings rates consumer expenditures of households grow very slowly, so the economy remains vulnerable to fluctuations in global demand, uneven and fragile. The Chinese government will increase the purchasing power, so we can expect demand growth for Ukrainian products, which will be aimed at domestic consumption - food, agricultural raw materials and industrial products will be used for the following processing. A different component of domestic demand is the social services 
development- medicine, science, education. As Ukraine has considerable experience in the social services provision, cooperation with Chinese partners (on condition the availability of a systematic approach of the Ukrainian side to cooperation) can significantly stimulate the export of services - educational, recreational, health, tourism and others. It is obvious that the price that we pay for "progress" of capital intensive and export-oriented development is becoming extremely high. For example, according to expert estimates, the costs associated with the deterioration of the environmental situation in the country in 2010 amounted to at least $\$ 230$ billion, i.e. around 3.5\% of China's GDP. Ukraine may get additional opportunities to participate in environmental projects in China, in parallel implementing effective solutions for Ukrainian enterprises. It may be the solution to the debt problem at the level of regions and enterprises [7].

The beginning of reforms and local governance in complex with the financial and fiscal reforms implementation could potentially change the investment policy model of the PRC in global markets. For example, according to the National audit office of China local governments at the level of provinces, counties, urban districts and cities the total debt has already reached 11 trillion yuan (1.8 trillion US dollars). This issue potentially threatens the stability of the banking system and may lead to a wave of irrevocable bank loans, which will paralyze the banking sector and will become a serious obstacle for reforms carrying out. In light of the accumulated risks and in prospect reduce of active trade balance Chinese power can reduce the investment volumes in other countries to raise requirements for foreign projects financing, change priorities for investment. The solution of energy problems, liberalization of pricing policies. Because these problems are topical for Ukraine, the government and enterprises of the two countries have many common areas for cooperation and exchange of experience and technologies. Now the question of the pricing policies revision in the energy sector is very serious. While the Chinese economy has been growing rapidly, the price of energy was artificially underestimated, because energy is a principal component of the Chinese economic model. Anticipating a sharp rise in inflation, the government has often interfered in the pricing process, ensuring that the price of electricity, coal and other energy sources could remain at the same level. However, the energy low cost has led to the fact that the incentive to increase the efficiency of the Chinese enterprises production has almost disappeared. The transition to higher energy prices that reflect their real value, will force Chinese enterprises to improve the efficiency of their production and develop cleaner production methods. Excessive centralization of the tax system has led to the lack of finances at the regional level. This caused to a permanent crisis of local budgets, the accumulation of "bad" municipal debt and sale of land for development, the pursuit of "customs" collection from export activities. autonomy of regional authorities for the development of territories will increase as solutions to these problems exists, so now it is advisable to develop the "horizontal" relations with China at the level of regional authorities and in the context of solving regional problems.

In the midterm it becomes possible to predict the further strengthening of international economic and political competitiveness of China and improving its activity in the global and regional processes. According to Chinese experts, the country has a resource in 10-15 years to a radical modernization of the economy and China admission to technological leadership. Subject to the focused and systematic foreign policy, the Ukrainian-Chinese cooperation will contribute to the solving a similar task of the economy modernization by the Ukraine. Cooperation is advisable to focus on several directions: cooperation in the sectors of complex machine building (the defense industry, aviation and shipbuilding, space industry); to attract Chinese investment in Ukrainian agriculture (a priority is for the productive and technological projects), establishment of new enterprises producing and processing agricultural products, the supply to the Chinese market a wide range of agricultural and food products; collaboration in the social services sector, tourism 
development, export of educational services; the development of cooperation in the sphere of transport services (priority - opening of a direct air route Beijing-Kiev); the attraction of Chinese investment to finance infrastructure projects and so on. Proper development of the Chinese (and generally Eastern) vector of foreign economic policy will allow Ukraine not only to attract additional investment, to preserve and enhance economic, defensive and scientific-technical potential, but also to benefit from the diversification of foreign economic cooperation, since countries in the Asia-Pacific region are becoming the "locomotives" of world economic development and have a significant weight in global politics [8].

In this context, it is appropriate to strengthen the effectiveness of the Ukrainian Executive authorities concerning relations development with China which involves: creating a predictable environment for attracting investment from China into the economy of Ukraine through the legislation improvement (benefits should be given to universal regulations stimulating investment in Ukraine foreign investment and technology transfer); the communication component strengthening in the bilateral relations, the dissemination of information about Ukraine and creation a positive image in the Chinese business circles (for example, placement of direct advertising in the Chinese media, events, etc.); limiting forms of cooperation with China, providing for the transfer to the Chinese party licenses for the products manufacturing (in this case China, generally, is phasing out import of production, setting up production of the same goods on its territory); removing artificial regulatory barriers (initiating relevant measures from the Chinese side) in the business way of two countries; the language barriers weakening in communication, promoting the Chinese and English languages study as tools of economic cooperation intensification; establishing humanitarian, cultural and scientific cooperation between the public, professional and business circles of two countries [9]. The implementation achieved on the highest level of Ukrainian-Chinese agreements, the filling of strategic partnership relations between two countries practical economic content, require from Ukraine the a comprehensive and coherent policy implementation that would take into account political, economic and financial weight of China in the modern world.

\section{Conclusion}

The made analysis of business relations between Ukraine and China at this stage allows selecting the following options for their development: 1 . The no availability of a clear government position in the points of "strong growth of Chinese goods imports " will lead to the fact that Ukraine in the nearest future will turn into a "raw materials appendage" not only for economically developed countries but for China and will also become the uncontrolled market for Chinese goods. 2. The state program development, providing for a shift in emphasis in the structure of exports to China. The basic principle of foreign policy of Ukraine should become turnover in raw materials export and cheap materials on the finished and high-tech products. But there must be a policy for such trade promotion. And the choice must be made as quickly as possible - no time to delay. Ukraine and the People's Republic of China have a real opportunity for qualitative and quantitative improvement of mutually beneficial cooperation in specific industries and economy sectors, however it is necessary to substantially revise the main provisions of the foreign policies of both countries. 


\section{References}

1. L. Vlasenko, Dominant tendencies of Ukrainian-Chinese trade development. Scientific Transactions of Kherson State University, (2017)

2. M. Vysotskaya, Analysis of the main tendencies in the development of economic relations between Ukraine and China. Strategy of development of Ukraine: economics, sociology, (2013)

3. V. Levkivsky, Ukrainian-Chinese Economic Cooperation in the Context of Foreign Economic Security. Scientific Bulletin of the Chernihiv State Institute of Economics and Management, (2013)

4. The World Bank [online], Available at: https://data.worldbank.org/country/china (2017)

5. State Statistics Service of Ukraine [online], Available at: http://www.ukrstat.gov.ua/operativ/operativ2008/zd/o eit/arh_o eit u.html (2017)

6. International trade center [online], Available at: http://intracen.org/ (2017)

7. Official site of the UN Statistics Division on International Trade. [online], Available at: https://comtrade.un.org/pb/CountryPagesNew.aspx?y=2015 (2017)

8. The National Institute for Strategic Studies [online], Available at: http://www.niss.gov.ua/articles/1359/ (2017)

9. UN Food and Agriculture Organization (FAO) [online]. Available at: http://www.fao.org/documents/card/en/c/463e6c11-c576-41f9-ae29-911bceb2924d (2017) 